\title{
Changes in northern Baltic zooplankton and herring nutrition from 1980s to 1990s: top-down and bottom-up processes at work
}

\author{
Juha Flinkman ${ }^{1, *}$, Eero Aro ${ }^{2}$, Ilppo Vuorinen ${ }^{3}$, Markku Viitasalo ${ }^{4}$ \\ ${ }^{1}$ University of Helsinki, Tvärminne Zoological Station, FIN-10900 Hanko, Finland \\ ${ }^{2}$ Finnish Game and Fisheries Research Institute, FIN-00151 Helsinki, Finland \\ ${ }^{3}$ Archipelago Sea Research Institute, FIN-20014 University of Turku, Finland \\ ${ }^{4}$ Department of Ecology and Systematics, Division of Hydrobiology, FIN-00014 University of Helsinki, Finland
}

\begin{abstract}
During the stagnation period of the Baltic Sea the mean weight-at-age of Baltic herring decreased by $50 \%$ (between 1977 and 1992). This has usually been attributed to a top-down process. i.e. to the simultaneous collapse of cod stocks and their predation. We present long-term data for 1980 to 1993 showing that bottom-up effects may also have played a role: along with the decline of salinity, the biomass proportion of zooplankton taxa preferred by herring (larger than $20 \mu \mathrm{g}$ ind.- ${ }^{-1}$ in wet weight) significantly declined. To support our hypothesis we present a study in which Baltic herring feeding and selective predation were investigated during 1985, a time of good growth and high weightat-age, and 1991, when herring growth and weight-at-age were poor. In this study, herring stomachs and simultaneously taken plankton samples were analysed from trawl surveys conducted in the northern Baltic proper during the peak of the herring feeding season in late summer. During both 1985 and 1991, herring selectively preyed on the larger zooplankton categories, especially neritic copepods. However, in 1991, a smaller proportion of the prey in herring stomachs consisted of neritic copepods, apparently because their share in plankton had decreased. Consequently, and despite an increase in total zooplankton biomass, the estimated carbon content of the food eaten by herring was lower, and the average stomach fullness index (on a scale of 0 to 5) decreased from 3.9 in 1985 to 1.9 in 1991 . Also, the amount of mesenteric fat on herring stomachs declined from 4.2 to 3.2 (scale 0 to 5 ), indicating a longer-term failure in feeding success. We suggest that, in addition to possible top-down effects (a release of cod predation), bottom-up processes mediated via changes in mesozooplankton species composition have also influenced herring growth and that both of these processes are affected by the same environmental factor - the Baltic salinity level.
\end{abstract}

KEY WORDS: Clupea harengus membras B Baltıc Sea Herring nutrition - Mesozooplankton - Selective predation - Top-down and bottom-up control

\section{INTRODUCTION}

During the stagnation period of the Baltic Sea (1977 to 1992) the growth of the Baltic herring Clupea harengus membras L. significantly declined (Anonymous 1994a). Weight-at-age of the Baltic herring was high at the beginning of the $1980 \mathrm{~s}$, but then decreased within a few years, by 30 to $50 \%$ for all age groups except the

- Correspondence address: Finnish linstitute of Marine Research, PO Box 33, FIN-00931 Helsinki, Finland.

E-mail: juha.flinkman@fimr.fi
0 and 1 groups (Anonymous 1994b). Their poor condition or starvation have become a considerable problem for fisheries and have also affected fisheries management in the Baltic. Due to underestimation of weightat-age, the International Council for the Exploration of the Seas (ICES) was off by as much as 30\% in its 1989 catch forecasts (Anonymous 1994a). Growth changes of this magnitude are not common for marine fish stocks in the temperate zone, although significant changes in Baltic herring weight-at-age have occurred prior to 1980 (e.g. Popiel 1951, Strzyzewska \& Popiel 1974) 
Potentially, either top-down or bottom-up effects, or both, could have caused the herring growth anomaly in the 1980s. Due to the lowering of the salinity and worsening of the oxygen conditions in early 1980s, cod recruitment decreased and the stock biomass declined within a few years (Bagge et al. 1994, Sparholt 1994). The collapse of Baltic cod populations has obviously removed a large portion of the predation pressure (Bagge et al. 1994, Anonymous 1996), which could lead to interspecific competition in herring. Also, cod predation is mainly directed towards small herring, which also affects herring weight-at-age (Sparholt \& Jensen 1992). It is therefore plausible to assume that top-down processes could have caused the herring growth anomaly (cf. Rudstam et al. 1994). On the other hand, the role of bottom-up regulation in herring growth is not clear. Baltic herring is a selective planktivore, preferring large-sized zooplankton species such as neritic calanoid copepods and ovigerous temales of copepods and cladocerans (Sandström 1980, Flinkman et al. 1992). If significant changes in the proportion of these species have taken place, feeding conditions of ihe Baitic ineniny may have worsented io a deyree where individual growth is affected.

This paper consists of 2 parts. First, we briefly review data on environmental variables that may have influenced herring populations and growth during 1980 to 1993. We will show data suggesting that, in concert with the decline of salinity and herring weight-at-age, the proportion of large-sized zooplankton preferred by herring has also declined. Second, we present a study in which Baltic herring feeding and selective predation were investigated in detail during 1985, a time of good growth and high weight-at-age, and 1991, when herring growth and weight-at-age were poor. Based on these data, we will discuss the relative roles of bottomup and top-down processes affecting herring growth in the Baltic Sea.

\section{MATERIALS AND METHODS}

Long-term data for $\mathbf{1 9 8 0}$ to 1993. In order to detect long-term changes in hydrography and mesozooplankton communities in our study area, we studied Helsinki Commission monitoring data collected in July to September 1980 to 1993 by the Finnish Institute of Marine Research (FIMR) from 3 relevant stations in the northern Baltic proper and western Gulf of Finland (monitoring stations LL7, LL12 and LL17; Fig. 1). During the cruises salinity was measured using a conductivity/temperature/depth (CTD)-probe and zooplankton samples were taken with vertical WP-2 net tows from bottom to halocline, from halocline to thermocline, and from thermocline to surface. Zooplankton samples were analysed in the FIMR laboratory using standard techniques for Baltic mesozooplankton (Anonymous 1984). Here we present salinity and zooplankton data integrated for the $\sim 0$ to $70 \mathrm{~m}$ layer at all stations.

To examine changes in cod and herring stocks, we used data compiled by ICES (Anonymous 1997), the Finnish Game and Fisheries Research Institute (FGFRI) (Aro et al. 1992) and the Estonian Marine Institute (Raid \& Lankov 1995). The ICES single-species virtual population analysis (S-VPA) data describe development of cod and herring populations; the Finnish and Estonian monitoring data provide weight-at-age values for all herring age groups for the northern Baltic proper (subdivision 29) and the western Gulf of Finland (subdivision 32). For simplicity, here we present only the average weight-at-age for herring 1 to $7 \mathrm{yr}$ old.

Herring selectivity study in 1985 and 1991. Study area and periods: The objective of the herring selectivity study was to find out which prey types herring select in the northern Baltic Sea and to check if any changes in herring stomach contents or selectivity took

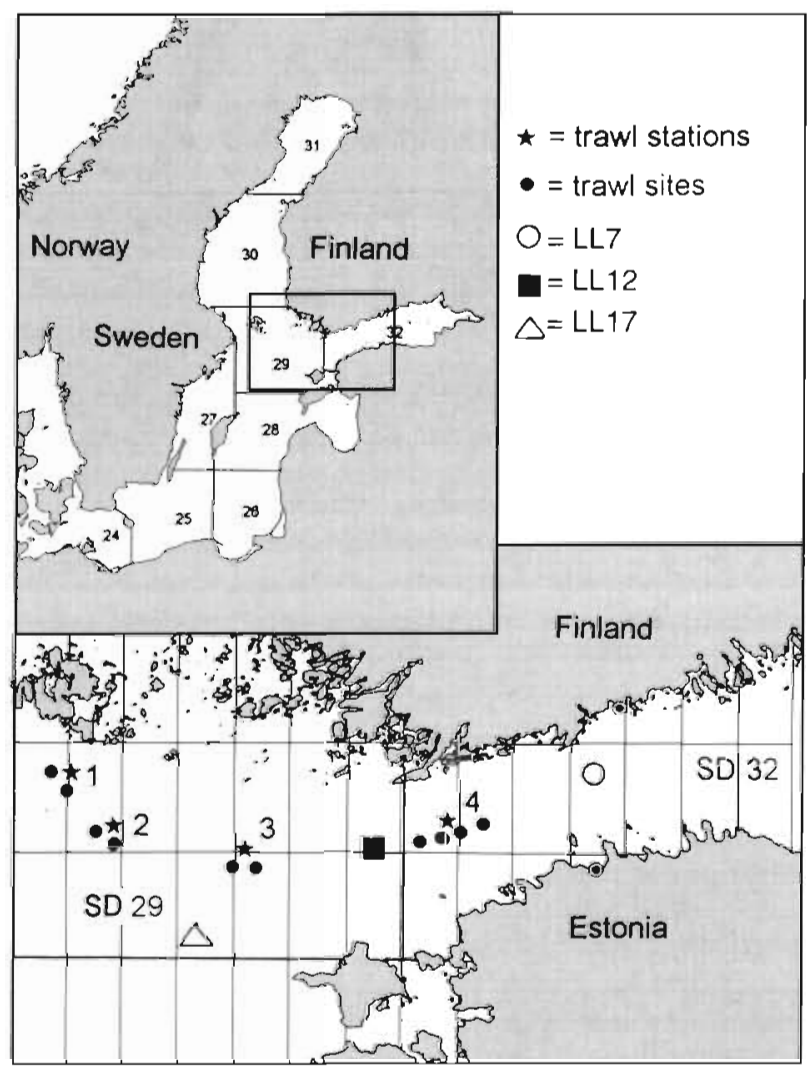

Fig. 1. Study area in the Baltic Sea, showing ICES sub-divisions (SD) in the northern Baltic proper (SD 29) and western Gulf of Finland (SD 32). Trawl stations in 1985 were Lảgskär (1) and Bogskär (2), and in 1991 Utö (3) and Jussarö (4). Location of monitoring stations LL7, LL12 and LL17 also shown 
place from the mid-1980s to the early 1990 s. The material examined, consisting of herring stomach samples and simultaneously taken plankton samples, was collected in 1985 and 1991 during FGFRI trawling surveys during the herring feeding period in AugustSeptember. In 1985, the samples were collected from 5 to 8 August, on 4 consecutive nights with 2 hauls taken on the first 2 nights (Stn 1) and a single haul during the 2 consecutive nights (Stn 2). In 1991, 6 hauls were taken from 9 to 14 August on 6 consecutive nights (Stns 3 and 4). The study area includes the northern part of the Baltic proper and western parts of the Gulf of Finland, in ICES sub-divisions 29 and 32 (Fig. 1). Each station consisted of 2 or 4 trawl sites located 10 nautical miles apart.

Plankton sampling: Plankton samples were taken using 2 different methods. In 1985 all plankton samples were taken with a $100 \mu \mathrm{m}$ mesh size WP-2 net; 3 vertical hauls were taken before and 3 after each trawl haul, from ca $25 \mathrm{~m}$, which is below the thermocline, to the surface. In 1991, both vertical and horizontal sampling were employed. Vertical sampling was performed as in 1985, and horizontal samples were taken by attaching 3 'nackthai'-type plankton samplers (mesh $100 \mu \mathrm{m}$ ) taken from Gulf $\mathrm{V}$ larval fish samplers (Schnack 1974) to trawl head and footropes. Plankton densities in the samples were calculated by multiplying the area of the sampler opening by the length of the haul. In 1985, 30 vertical WP-2 hauls were taken, whereas in 1991, 6 vertical WP-2 and 18 horizontal nackthai-samples were taken.

Fish sampling: The fish were caught with a $500 \mathrm{ft}$ (ca $152 \mathrm{~m}$ ) pelagic Larsen research trawl. The trawl hauls were taken during the night, when fish could be found, by means of an echo sounder, just under the thermocline at depths between 10 and $30 \mathrm{~m}$. The trawl was hauled for $1 \mathrm{~h}$, after which 20 to 50 sample fish were chosen at random from the catch. Catch size varied between 60 and $1000 \mathrm{~kg}$ (average $130 \mathrm{~kg}$ ). The sample fish were examined for length, weight and sex. Otoliths were preserved for age reading and stomachs preserved in $4 \%$ buffered formaldehyde, all within $15 \mathrm{~min}$ of trawl recovery. A total of 170 fish were analysed in 1985 and 200 in 1991. The size range of the fish selected for stomach content analysis was 150 to $170 \mathrm{~mm}$. This size distribution was dictated by the availability in both 1985 and 1991 of fish that were comparable with respect to 3 factors: length, catchdepth and sampling area. The age of the sample fish varied from 2 to $6 \mathrm{yr}$, which means that they mostly belonged to the spawning stock (Parmanne 1990).

Plankton analyses: Zooplankton samples were analysed using standard techniques recommended for Baltic mesozooplankton (Anonymous 1984). Plankton was identified according to species; copepods were classified according to their developmental stage and sex (nauplii were excluded because a $100 \mu \mathrm{m}$ mesh net does not sample them quantitatively); cladocerans were grouped to ovigerous and non-ovigerous. To ascertain the comparability of the 2 sampling methods used in 1991, the vertical and horizontal samples were compared with a Student's $t$-test. The test indicated no significant difference, so we assumed the sampling methods to be comparable. In examining the plankton samples and stomach contents, the plankton was categorised by their size according to Hernroth (1985) and FIMR (unpubl.) (Table 1). This categorisation includes, besides different species, also different sexes and developmental stages of plankters, as they differ considerably in size.

Analyses of herring stomachs and selectivity: Stomachs of 20 to 50 fishes from each trawl haul were used to estimate stomach fullness and mesenteric fat (both on a scale of 0 to 5 ) and to identify prey species. Plankton in herring stomachs was identified using 2 methods. If the contents were well preserved, they were emptied into a standard plankton counting chamber and identified with an inverted microscope. However, if the stomach contents were more digested, they were fixed onto a microscope slide with glycerol and identified with a compound microscope. A total of

Table 1. Size-ranked mesozooplankton categories. Cop: copepodites; f: adult females; m: adult males; of: ovigerous females. Source: Hernroth (1985) and Finnish Institute of Marine Research (unpubl.)

\begin{tabular}{|c|c|c|}
\hline $\begin{array}{l}\text { Size } \\
\text { rank }\end{array}$ & $\begin{array}{l}\text { Identification } \\
\text { category }\end{array}$ & $\begin{array}{l}\text { Wet weight } \\
\left(\mu g \text { ind }^{-1}\right)\end{array}$ \\
\hline 1 & Acartia spp., cop & 12 \\
\hline 2 & Eurytemora affinis, cop & 14 \\
\hline 3 & Bosmina longispina maritima $f$ & 15 \\
\hline 4 & Bosmina longispina maritima of & 15 \\
\hline 5 & Temora longicornis, cop & 15 \\
\hline 6 & Centropages hamatus, cop & 15 \\
\hline 7 & Acartia spp., m & 17.5 \\
\hline 8 & Pseudocalanus elongatus, cop & 20 \\
\hline 9 & Eurytemora affinis, $\mathrm{m}$ & 20 \\
\hline 10 & Evadne nordmanni, f & 20 \\
\hline 11 & Evadne nordmanni, of & 20 \\
\hline 12 & Acartia spp., f & 22.5 \\
\hline 13 & Podon polyphemoides, i & 25 \\
\hline 14 & Podon polyphemoides, of & 25 \\
\hline 15 & Eurytemora affinis, $\mathrm{f} / \mathrm{of}$ & 30 \\
\hline 16 & Pseudocalanus elongatus, $m$ & 35 \\
\hline 17 & Centropages hamatus, m & 40 \\
\hline 18 & Temora longicornis, $\mathrm{m}$ & 45 \\
\hline 19 & Centropages hamatus, f & 45 \\
\hline 20 & Pseudocalanus elongatus, f/of & 50 \\
\hline 21 & Limnocalanus macrurus, cop & 50 \\
\hline 22 & Temora longicornis, f & 60 \\
\hline 23 & Podon intermedius, $\mathrm{f}$ & 200 \\
\hline 24 & Podon intermedius, of & 200 \\
\hline 25 & Limnocalanus macrurus, $\mathrm{m}$ & 454 \\
\hline 26 & Limnocalanus macrurus, $f$ & 810 \\
\hline
\end{tabular}


100 individual plankters were identified from each sample by counting the carapaces. This number was determined by a preliminary test in which successive groups of 20 zooplankton individuals were identified from stomachs of 5 different fish until the variation in the proportional abundance of different size categories levelled off (Elliott 1971).

To describe selective feeding, we calculated chisquared based indices $V= \pm\left(\chi^{2} / n\right)^{1 / 2}$ and $C= \pm\left(\chi_{y}{ }^{2} / n\right)^{1 / 2}$ (Pearre 1982), using the average abundance percentages for each size category in stomachs and in respective plankton samples. These indices vary between 1 and -1 , corresponding to absolute selection and rejection, respectively. Since the $V$-index was less sensitive to outliers in our data, we used it instead of the $C$ index. Significance of selection indices was tested with Fisher's exact test, as recommended by Pearre (1982).

To estimate the energetic value of the stomach contents in 1985 and 1991, we used the following method. Individual carbon contents of Baltic mesozooplankton categories have been analysed at the Finnish Institute of Marine Research using the high temperature com-

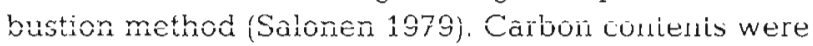
available for copepodites and adults of Acartia spp., Eurytemora affinis and Temora longicornis (Table 2), which are the most abundant copepod species in the study area. To obtain an energy index for these size categories in herring stomachs, their carbon contents were multiplied with their average frequency in herring stomachs in 1985 and 1991, and then multiplied by the average stomach fullness estimates for these 2 years.

\section{RESULTS}

\section{Long-term changes during 1980 to 1993}

During the period 1980 to 1993, average salinity in the 0 to $70 \mathrm{~m}$ layer decreased from $\sim 7.5$ to $6.3 \%$ (Fig. 2A),

Table 2. Carbon contents of mesozooplankton categories used in estimating the energetic content of herring stomach contents. Source: Finnish Institute of Marine Research (unpubl.). Cop: last copepodite stages, f: adult females, m: adult males

\begin{tabular}{|clc|}
\hline $\begin{array}{c}\text { Size } \\
\text { rank }\end{array}$ & $\begin{array}{l}\text { Identification } \\
\text { category }\end{array}$ & $\begin{array}{c}\text { Carbon content } \\
\left(\mu \mathrm{g} \mathrm{C} \text { ind }{ }^{-1}\right)\end{array}$ \\
\hline 1 & Acartia sp., cop & 0.879 \\
2 & Eurytemora affinis, cop & 1.131 \\
5 & Temora longicornis, cop & 1.129 \\
7 & Acartia sp., m & 1.369 \\
9 & Eurytemora affinis, $\mathrm{m}$ & 1.368 \\
12 & Acartia sp., f & 1.486 \\
15 & Eurytemora affinis, $\mathrm{f}$ & 1.420 \\
18 & Temora longicornis, $\mathrm{m}$ & 1.588 \\
22 & Temora longicornis, $\mathrm{f}$ & 2.059 \\
& & \\
\hline
\end{tabular}

and changes in mesozooplankton communities also occurred. Of these changes, most prominent were: an increase in the numbers of rotifers such as Synchaeta spp.; an increase of cladocerans, especially Bosmina longispina maritima; and a decrease in the abundance of neritic copepod species, such as Pseudocalanus elongatus (Anonymous 1996 and the present data). Consequently, between 1980 and 1993 the biomass proportion of plankton taxa larger than $20 \mu \mathrm{g}$ ind $^{-1}$ during July to September significantly decreased at the 3 stations studied (Fig. 2B; Pearson correlation with time $-0.68, p=0.011$ ). Meanwhile, the total mesozooplankton biomass (the vertical bars in Fig. 2B) varied with no obvious trend. During the same period the cod stock collapsed, whereas herring numbers remained at a high level during 1981 to 1985, were lower in 1986 to 1989 , and thereafter started to increase again (Fig. 2C). Meanwhile, the average weight-at-age of herring declined by $50 \%$, from $38 \mathrm{~g}$ in 1983 to $19 \mathrm{~g}$ in 1993 (Fig. 2D). This decline in individual weight also contributed to a decline in herring population biomass during the respective years (continuous line in Fig. 2C).

Iabie 3 shows correlations calculated between the mean values of salinity, zooplankton biomass, proportion of larger plankters $\geq 20 \mu \mathrm{m}$ ind. ${ }^{-1}$ (PLP), cod and herring numbers and biomass, and herring weight-atage (WAA) in 1980 to 1993. The correlation matrix shows that PLP, herring biomass, cod abundance and biomass and herring WAA all correlated positively with salinity, whereas the total zooplankton biomass showed a weaker negative correlation with salinity. Herring WAA also correlated positively with PLP, herring biomass and cod abundance and biomass. In contrast, herring abundance did not correlate with any of the variables considered.

\section{Herring selective predation in 1985 and 1991}

\section{Plankton}

In 1985 there were more larger mesozooplankton categories in the samples, compared to 1991. (Fig. 3A), which agrees with the long-term data (cf. the continuous line in Fig. 2B). The significance of the difference was verified by dividing the plankton data into 2 parts, small categories $\left(<20 \mu \mathrm{g}_{\text {ind }} \mathrm{-}^{-1}\right)$ and larger categories ( $\geq 20 \mu \mathrm{g} \mathrm{ind}^{-1}$ ); according to the non-parametric Wilcoxon test of medians, the decline was significant for the larger categories $(p=0.02)$. Fig. $3 B$ shows the data grouped into 4 size categories. The increase of the smallest size group $\left(<20 \mu \mathrm{g}\right.$ ind $\left.{ }^{-1}\right)$ was mainly caused by an increase in the proportion of Bosmina longispina maritima. In the 2 larger size groups $(20$ to 40 and 40 to $60 \mu \mathrm{g}$ ind. ${ }^{-1}$ ), the relative proportion of all 
A) SALINITY

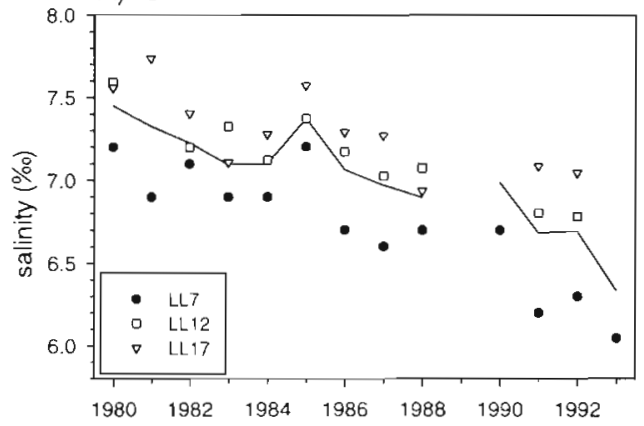

B) ZOOPLANKTON

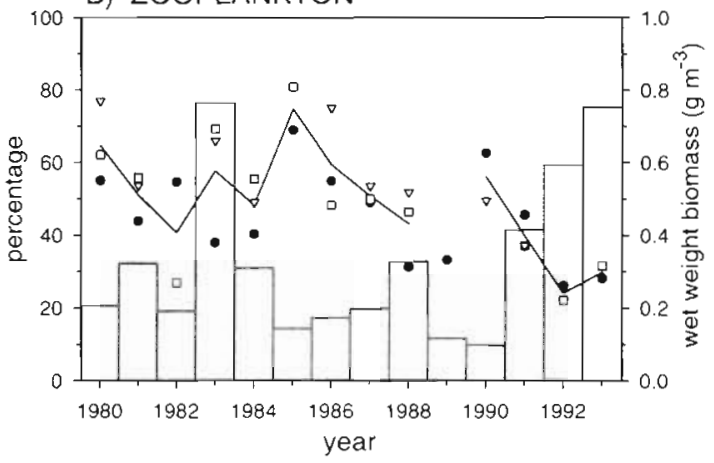

C) FISH STOCKS

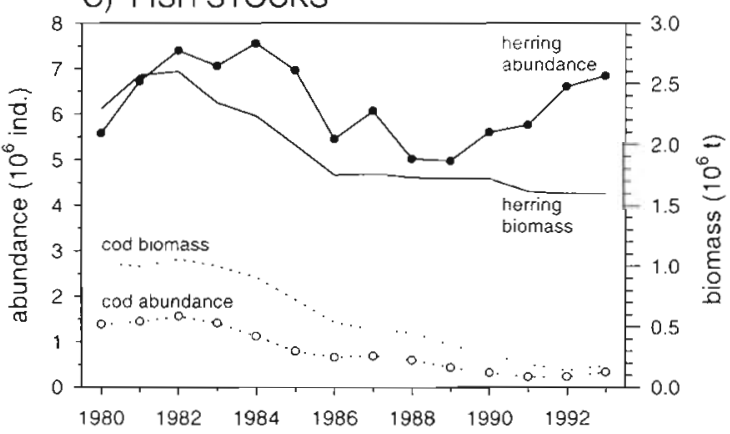

D) HERRING WEIGHT-AT-AGE

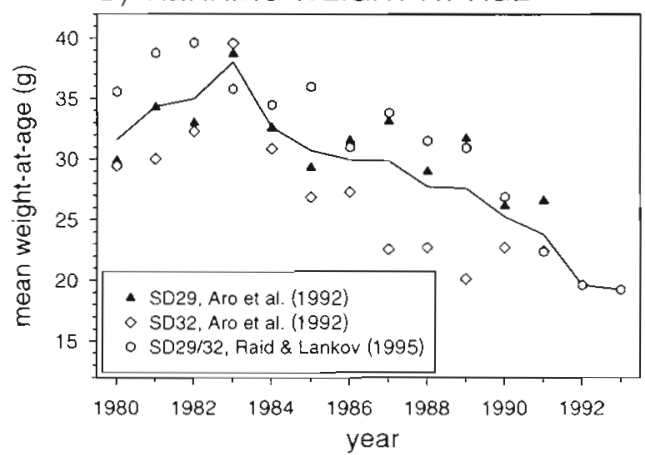

Fig. 2. Long-term data for the western Gulf of Finland and northern Baltic proper in the period 1980 to 1993. (A) Salinity in July to September at Baltic monitoring stations LL7, LL12 and LL17 (line broken due to incomplete data for 1989); (B) biomass proportion of zooplankters $\geq 20 \mu \mathrm{g}_{\text {ind. }}{ }^{-1}$ (symbols and line), and total mesozooplankton biomass (vertical bars) in July to September, in the 0 to $70 \mathrm{~m}$ water layer, at Stns LL7, LL12 and LL17 (symbols as in A) (line broken due to incomplete data for 1989); (C) population densities and biomass of herring and cod stocks in the ICES subdivisions 29 (northern Baltic proper) and 32 (western Gulf of Finland); (D) average weight-at-age for 1 to 7 yr old herring in the ICES subdivisions 29 and 32 (from Aro et al. 1992 and Raid \& Lankov 1995). In (A), (B) and (D), the lines (and vertical bars in B) indicate average values for 3 stations (in $A$, the mean value for 1990 and 1993 was estimated from the mean difference between average salinity and salinity at Stn LI 7 during the other years)

categories had decreased. The largest size group (200 to $810 \mu \mathrm{g} \mathrm{ind}^{-1}$, which consists of the relatively scarce Podon intermedius and Limnocalanus macrurus) showed no marked change. Yet, the overall decrease in the relative proportion of larger sized individuals did not affect the total plankton biomass; in fact the individual biomass multiplied by their abundance showed an increase in all size groups (Fig. 4), again consistently with the long-term data (cf. the vertical bars in Fig. 2B).

Table 3. Long-term data for the western Gulf of Finland and northern Baltic proper in 1980-1993. Linear Pearson correlation coefficients ( $r$, multiplied by 100) between the average salinity, total mesozooplankton biomass in the $\sim 0$ to $70 \mathrm{~m}$ layer, proportion of large plankters $\geq 20 \mu$ ind $^{-1}$ in wet weight (PLP), herring abundance and biomass, cod abundance and biomass, and herring weight-at-age (WAA). Time series correspond to lines in Fig. 2, denoting average values for each time series (for zooplankton total biomass in Fig. 2B: vertical bars). $N=13$. Significance: $" p<0.05 ; \cdots p<0.01 ; \cdots p<0.001$

\begin{tabular}{|c|c|c|c|c|c|c|c|c|}
\hline & Year & Salinity & $\begin{array}{l}\text { Zoo- } \\
\text { plankton } \\
\text { biomass }\end{array}$ & PLP & $\begin{array}{c}\text { Herring } \\
\text { abundance }\end{array}$ & $\begin{array}{l}\text { Herring } \\
\text { biomass }\end{array}$ & $\begin{array}{c}\text { Cod } \\
\text { abundance }\end{array}$ & $\begin{array}{c}\text { Cod } \\
\text { biomass }\end{array}$ \\
\hline Salinity & $-91 \cdots$ & & & & & & & \\
\hline Zooplankton biomass & 36 & $-61^{\circ}$ & & & & & & \\
\hline PLP & $-68^{\prime}$ & $69^{\prime \prime}$ & -37 & & & & & \\
\hline Herring abundance & -25 & 10 & 31 & -26 & & & & \\
\hline Herring biomass & $-91 \cdots$ & $75 \cdots$ & -15 & 37 & 52 & & & \\
\hline Cod abundance & $-95 \cdots$ & $76^{\cdots}$ & -13 & 48 & 44 & $97 \cdots$ & & \\
\hline Cod biomass & $-97 \cdots$ & $83^{\cdots} \cdot$ & -22 & $57^{\circ}$ & 42 & $95 \cdots$ & $98 \cdots$ & \\
\hline Herring WAA & $-91 \cdots$ & $81 \cdots$ & -27 & $68^{\circ}$ & 31 & $85 \cdots$ & $90 \cdots$ & $92 \cdots$ \\
\hline
\end{tabular}



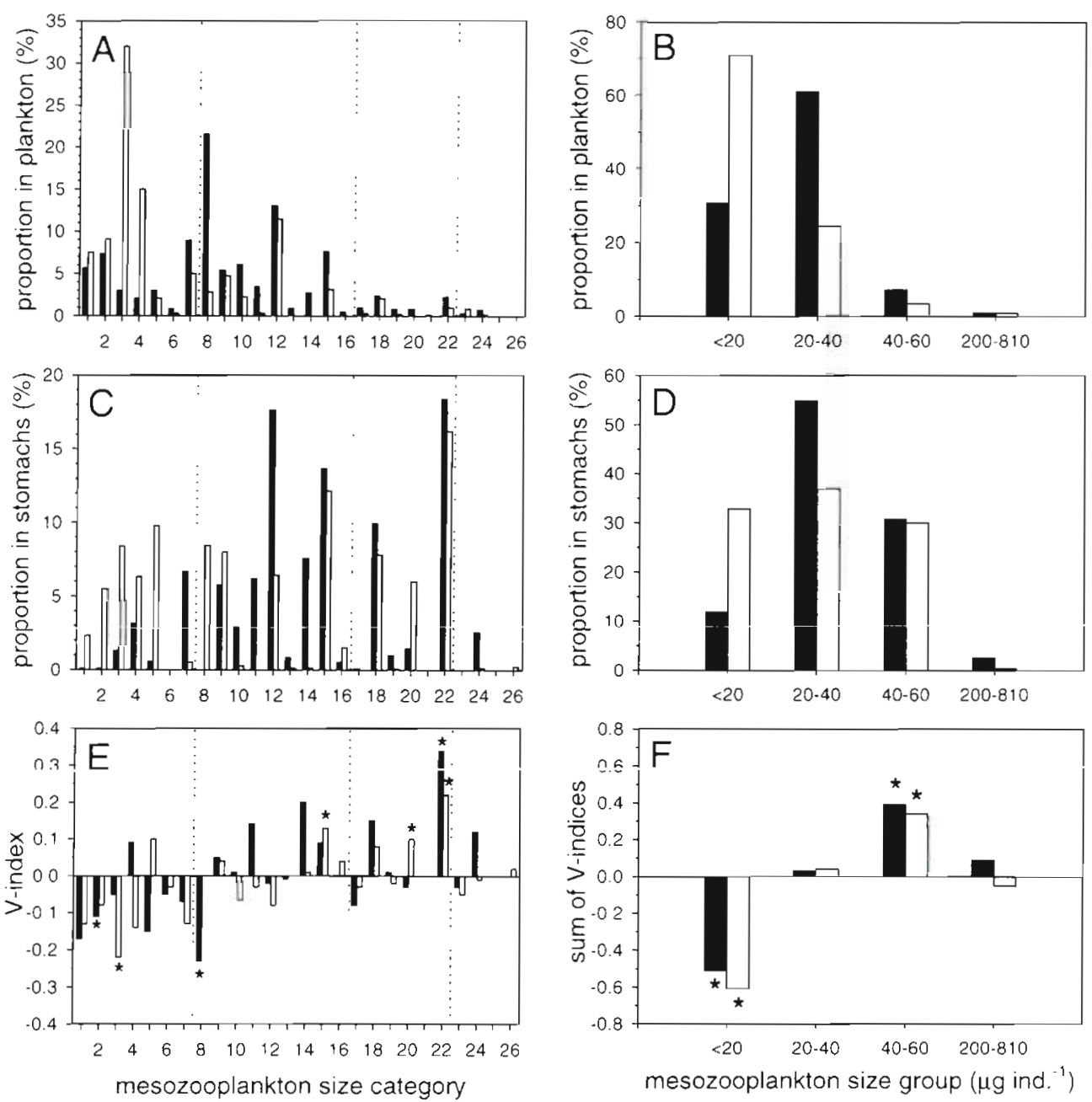

Fig. 3. Clupea harengus membras. Selectivity study. (A) \& (B) relative proportions of mesozooplankton categories in plankton; (C) \& (D) relative proportions of the same categories in herring stomach samples; (E) \& (F) hernng selectivity indices $V$. Black columns indicate 1985, white columns 1991. Original data in left-hand panels; vertical lines divide mesozoopiankion categories into 4 size groups shown in right-hand panels. In (E) \& $(F)$ the significance of selection was tested with Fisher's exact test, p-values $<0.05$ indicated with $:$ For zooplankton categories refer to Table 1 Note that there were no taxa with wet weights between 60 and $200 \mu$ ind $^{-1}$

Stomach contents

The most abundant food items in herring stomachs were Temora longicornis adults, Eurytemora affinis females and, in 1985, Acartia bifilosa females. In 1991, T. longicornis copepodids and Bosmina longispina maritima were also relatively abundant (Fig. 3C). Nevertheless, the stomach contents showed the same trend as plankton composition: in 1985 the herring fed relatively more on larger plankters, whereas in 1991 the smaller categories were eaten to a greater extent (Fig, 3D). This difference was significant for the smallest categories (wet weight $<20 \mu \mathrm{g} \mathrm{ind.-1}$ ) (Wilcoxon test of medians for hypothesis $1991>1985$, $p=0.038$ ).

\section{Selectivity}

Herring selective predation was measured using the $V$-index (Pearre 1982). There was a clear tendency towards a negative selection of smaller categories and a positive selection of larger ones (Fig. 3E). Especially the females of Temora longicornis, Eurytemora affinis and Pseudocalanus elongatus were selected as food. We then combined the data into 4 size classes (Fig. 3F) and calculated the sum of $V$-indices for these size classes. Negative selection in the smallest size class $\left(<20 \mu \mathrm{g}\right.$ ind. $\left.^{-1}\right)$ and positive selection in the third size

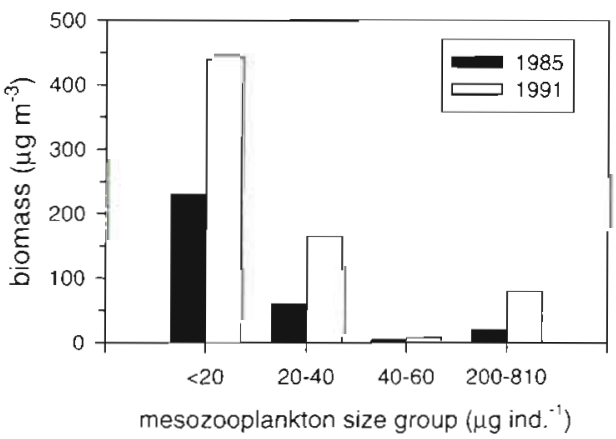

Fig. 4. Clupea harengus membras. Selectivity study. Total mesozooplankton biomass during 1985 and 1991, grouped into 4 size categories 
A) STOMACH FULINESS

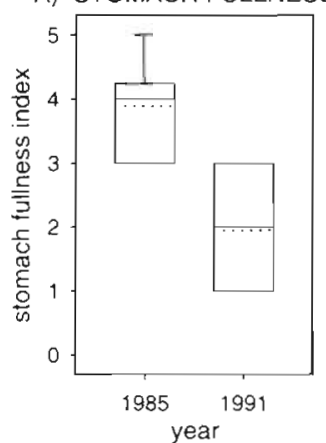

B) MESENTERIC FAT

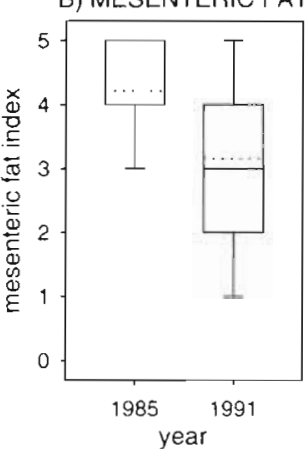

Fig. 5. Clupea harengus membras. Selectivity study. Box plots for (A) stomach fullness and (B) amount of mesenteric fat on herring stomachs, both measured on a scale of 0 to 5 . Continuous line in the middle of each box indicates median of the data; dotted line indicates the average; ends of boxes indicate the 25 and 75 th percentiles; ends of whiskers indicate 10 and 90th percentiles of the data

class (40 to $60 \mu \mathrm{gg}$ ind ${ }^{-1}$ ) were significant during both years (Fisher's exact test, $\mathrm{p}<0.001$ ). Differences in food selection between 1985 and 1991 were tested with Wilcoxon test of medians for all categories $(\mathrm{p}=$ 0.4 ), and for the 4 size groups ( $p=0.6$ ), and were not significant in either the smaller or the larger categories. This suggests that herring food preferences did not change between 1985 and 1991

Energetic value of stomach contents

Differences in stomach contents in 1985 and 1991 were not restricted to species composition of the food. The average stomach fullness estimates were 3.9 and 1.9 for 1985 and 1991, respectively (Fig. 5A), despite the higher zooplankton biomass in 1991 (cf. Fig. 4). Also, the average amount of mesenteric fat on herring stomachs declined from 4.2 to 3.2 (Fig. 5B). This

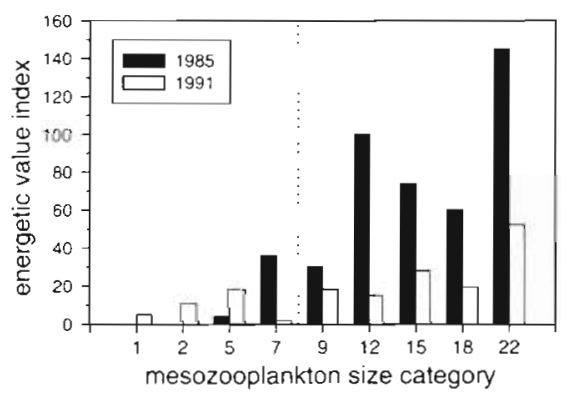

Fig. 6. Clupea harengus membras. Selectivity study. Energy content indices for zooplankton categories in herring stomachs in 1985 and 1991. Vertical dashed line divides categories into smaller $\left(<20 \mu \mathrm{g}\right.$ ind $\left.^{-1}\right)$ and larger categories $(\geq 20 \mu \mathrm{g}$ ind. ${ }^{-1}$ ). For zooplankton categories refer to Table 2 decline was very significant for both variables (Student's $t$-test, $\mathrm{p}<0.001$ in both cases).

To estimate the energy contents of the food ingested we needed to take into account both the energetic value of the individual prey items and the stomach fullness. Fig. 6 shows the indices obtained by multiplying the average proportions of Acartia bifilosa, Eurytemora affinis and Temora longicornis in herring stomachs in 1985 and 1991 by their individual carbon contents (from Table 2) and then by the stomach fullness estimates from the respective years (3.9 in 1985 and 1.9 in 1991). The herring stomachs contained more carbon in the larger mesozooplankton categories $\left(\geq 20 \mu \mathrm{g} \mathrm{ind} .^{-1}\right.$, here represented by $E$. affinis and $T$. longicornis adults and Acartia spp. females) in 1985 than in 1991 (Wilcoxon test of medians, $1985>1991, p=0.006$ ). In contrast, the amount of carbon in herring stomachs in the smaller categories $\left(<20 \mu \mathrm{g}_{\text {ind }} \mathrm{-}^{-1}\right.$, here Acartia spp., $E$. affinis and $T$. longicornis copepodites and Acartia males) was larger in 1991 than in 1985 (Wilcoxon, p = $0.04)$.

\section{DISCUSSION}

Our results showed that (1) Baltic herring prey selectively on larger zooplankton taxa; no change in this pattern took place during the period studied; (2) the availability of prey types larger than $20 \mu \mathrm{g}$ ind $^{-1}$ declined during the stagnation period of the Baltic; (3) the composition of herring stomachs reflected the availability of preferred food items; and consequently (4) the stomach fullness and the energy content of stomachs declined. This suggests that the herring growth anomaly was at least partly caused by a bottom-up process. Below we will consider the mechanisms by which bottom-up and top-down processes may have influenced herring WAA during the study period.

\section{Baltic hydrography, plankton and herring nutrition}

Fluctuations in salinity are typical for the Baltic Sea. These fluctuations are caused by interactions between continuous excessive freshwater runoff from the Baltic drainage basin and time-limited, irregular saline water intrusions from the North Sea. During the period 1980 to 1993 the salinity in the Baltic decreased due to the absence of saltwater intrusions from the North Sea (Matthäus \& Franck 1992, Anonymous 1996) and due to an exceptionally rainy period from 1981 to 1990 (Bergström \& Carlsson 1994). Salinity and temperature tolerances of mesozooplankton species largely determine their horizontal and vertical distribution (Segerstråle 1969), and the effect of hydrographical factors on 
the spatial distribution of planktonic species has been demonstrated (e.g. Hernroth \& Ackefors 1979). A decrease in salinity also correlates inversely with the occurrence of neritic copepod species like Pseudocalanus elongatus, Temora longicornis and Centropages hamatus, and positively with the occurrence of small cladocerans, especially Bosmina longispina maritima (Lumberg \& Ojaveer 1991, Viitasalo et al. 1995, Anonymous 1996). On the other hand, stratification patterns, also coupled with hydrographical processes, are known to influence the structure of planktonic communities (Richardson 1985, Kiørboe \& Johansen 1986, Kiørboe 1993). For example on the SW coast of Finland, warm, low saline and stable hydrographical conditions induce a rapid increase in cladoceran populations, whereas mixed and more saline conditions favour neritic calanoid copepods (Viitasalo et al. 1995); in the Skagerrak the mixed regions have also been shown to support a copepod-dominated grazing chain, whereas the stratified areas are dominated by the organisms of the microbial loop (Kiørboe et al. 1990).

Changes in salinity and stratification thus have both direct and indirect effects on pelagic organisms and communities. In the northern Baltic Sea it seems that the changes that took place in the 1980 s disfavoured zooplankton groups valuable for the Baltic herring. According to planktivorous fish foraging models, herring should select larger plankters (Lazarro 1987), which was, with minor exceptions, also confirmed by the present study. A comparison of herring selectivity between 1985 and 1991 revealed no significant differences in this pattern, which suggests that herring are not able to fully compensate for the decrease in preferred prey. Therefore, as the proportion of suitably sized food decreased, the herring were compelled to forage on small-sized, low-energy food, which was also reflected in their stomach fullness.

There were no reported changes in herring maturityat-age (Anonymous 1994a) or spawning time (Parmanne et al. 1994) in the northern Baltic Sea during our study period. Therefore we believe that the differences in stomach contents between 1985 and 1991 indicate a general trend in herring feeding ecology. Research by Lumberg \& Ojaveer (1991) also showed this same phenomenon for the same period and the same study area, i.e. a decrease in neritic plankters, such as Pseudocalanus elongatus, Temora longicornis and Centropages hamatus, as well as a decrease in herring WAA. The observed decline in the amount of mesenteric fat also supports the hypothesis of declined energy gain in herring. Mesenteric fat is labile, unlike muscle fat, and is used to build up gonads before spawning (Ojaveer et al. 1981, Rajasilta 1992). Hence, we assume that the amount of mesenteric fat reflects the herring feeding success

\section{Top-down or bottom-up control of herring growth?}

Decrease in salinity and stagnation of the deep water have affected the reproduction of cod, the most important predator of Baltic herring. Cod eggs require $11 \%$ salinity and an oxygen content $>2 \mathrm{ml} \mathrm{l}^{-1}$ to survive and hatch (Nissling \& Westin 1991, Westin \& Nissling 1991, Wieland et al. 1994). Mainly due to the absence of oxygen-carrying saltwater intrusions between 1977 and 1992, cod recruitment decreased sharply in 1980, and the spawning stock biomass started to decline from 1983 onwards (Bagge et al. 1994, Sparholt 1994; for other contributing factors, see Mackenzie et al. 1996). With the decimation of the cod stock the amount of herring eaten also decreased by half from 1985 to 1991 (Anonymous 1997). There is no evidence that this predation was replaced by other predators. The impact of salmon and sea trout predation on herring stocks is insignificant (A nonymous 1997); marine mammal populations remained at very low levels (Thürow 1997) and the abundance of seagull species (Larus spp.) that prey on herring decreased during the study period (Hario 1990). Seen in this light, the population increase of herring in the late 1980 s seems like the result of a clear-cut top-down regulation process, as suggested by Rudstam et al. (1994).

In contrast, it is less obvious that the decline in herring WAA was caused by a top-down process. If we conclude that the decline in herring growth was caused by increased density, we must assume that the herring population increased to a degree to which there was intraspecific competition that reduced food ingestion per individual. This also implies that herring populations are able to control zooplankton biomass. However, although ca $70 \%$ of the annual zooplankton production is estimated to be consumed by herring in the northern Baltic (Hansson et al. 1990, Rudstam et al. 1992, Arrhenius 1995), there is no evidence that Baltic zooplankton biomass are affected by interannual variations in herring stocks (Rudstam et al. 1994). This apparent discrepancy can be explained by our findings, which suggest that herring feeding is not limited by the total amount of zooplankton, but by the availability of suitably sized plankters. This would essentially imply a bottom-up process, since the structure of the zooplankton community seems to be largely regulated by the environment, i.e. changes in the hydrography and stratification of the Baltic Sea. An analogous situation has been observed in the frontal regions of the North Sea, where physically mixed areas are characterised by a food web dominated by copepods and support high growth of planktivorous fish larvae, whereas the stratified regions are characterised by organisms of the microbial loop and support low growth of fish larvae (Munk 1993, Munk et al. 1995 , St. John \& Lund 1996). 
According to our analysis, herring WAA was negatively correlated with salinity and positively correlated with the proportion of large plankters, herring biomass and with cod abundance and biomass. Of these variables, salinity itself cannot be the proximate factor, because there is no physiological mechanism linking small changes in salinity with fish growth. The connection with cod variables also seems incidental because there was no link between herring and cod numbers; if herring WAA was controlled by a top-down process, one would expect herring numbers to reflect this. It is also notable that herring WAA had already started to decline several years before the herring population showed an increase (cf. Fig. 2c). This leaves us with the correlation between herring WAA and the proportion of large plankters as being the most plausible one. Of course, we recognise that correlations between time series do not prove a causal relationship and that we do not have herring stomach content data for more than 2 yr. We however note that, in the 2 independent studies (the selection study and the long-term investigation), the trends observed in plankton composition, herring WAA, stomach fullness and amount of mesenteric fat very consistently point the same direction: declined food availability for herring. We therefore suggest that bottom-up regulation, mediated through changes in zooplankton community, is an explanation for the observed decline in herring growth which is at least as credible as top-down control

On the other hand, there are certain complications in the matter. As Baltic herring grows, it begins to feed on larger organisms, such as mysids and amphipods (Aneer 1980, Flinkman et al. 1991). Arrhenius \& Hansson (1993) have proposed that a mixed diet is essential for maintaining a good WAA in older herring and that a decline of mysids (mainly Mysis mixta and $M$. relicta) in herring diet could also explain the growth anomaly. Unfortunately there is no information about changes in mysid populations during the Baltic stagnation period. Also, little is known about their food preferences, and it is therefore difficult to estimate how the changes in zooplankton communities have affected the feeding and reproduction of mysids in the Baltic Sea.

\section{Conclusions}

We suggest that the 1980s herring growth anomaly was caused by 2 processes. A changed mesozooplankton species composition caused bottom-up restrictive effects due to a worsening of herring feeding conditions. The collapse of cod stocks also led to a situation where herring experienced intraspecific competition resulting in adverse effects on growth. In addition, interspecific competition with sprat and mysids, and changes in mysid populations, may also be involved. To solve the question of which process is dominant, it is first necessary to determine how the changes in plankton and herring numbers influenced the intake of food for an individual herring. This could be done by combining population dynamical analyses with experimental studies in which behavioural factors, such as foraging success on different prey types and the intraspecific competition within a herring school, are considered. It is also notable that both top-down and bottom-up processes are influenced by the same factor, Baltic salinity, and that they both work towards decreased herring growth and condition. Baltic salinity is controlled by inflows of saline water from the North Sea and by variations in freshwater runoff (Astok et al. 1990). These factors, in turn, are both regulated by climatic patterns, such as air pressure gradients over the north Atlantic and the North Sea (Matthäus \& Schinke 1994) and precipitation over the Baltic drainage area (e.g. Viitasalo et al. 1995). By combining relevant data for air pressure, precipitation and freshwater runoff, one might be able to predict changes in Baltic hydrography and, hence, to anticipate trends in the growth rate of Baltic herring.

Acknowledgements. We thank Harri Kuosa and Soili Saesmaa (Finnish Institute of Marine Research) for mesozooplankton carbon content data, zooplankton analyses and fruitful discussions, and the skippers and crew of the trawler 'Rossvik SF-800' for their help in sampling and their extensive knowledge about herring behaviour. We also thank Brian McKenzie, Mike St. John and 4 anonymous referees for their constructive comments. This research has been partly funded by the Walter and Andrée de Nottbeck Foundation.

\section{LITERATURE CITED}

Aneer G (1980) Estimates of feeding pressure on pelagic and benthic organisms by Baltic herring (Clupea harengus v. membras L.). Ophelia 1:265-275

Anonymous (1984) Baltic Sea environment proceedings no. 12. Guidelines for the Baltic monitoring programme for the second stage. Baltic Sea Environment Protection Commission-Helsinki Commission, Helsinki

Anonymous (1994a) Growth changes of herring in the Baltic. TemaNord 1994:532

Anonymous (1994b) Report of the working group on multispecies assessment of Baltic fish. ICES CM 1994/Assess:1

Anonymous (1996) Baltic Marine Environment Protection Commission, Helsinki Commission. Third periodic assessment of the state of the marine environment of the Baltic Sea, 198993; Background document. Baltic Sea Environ Proc 64B

Anonymous (1997) Report of Baltic fisheries assessment working group 14-23 April 1997. Copenhagen. ICES CM 1997/Assess: 12

Aro E, Kotilainen P, Flinkman J (1992) Changes in the growth rate of Baltic herring: why some specimens are starved in the northern Baltic. ICES CM 1992/J:4

Arrhenius F (1995) Feeding ecology of Baltic Sea herring (Clupea harengus L.) - field and model studies of a dominant zooplanktivore. Doctoral thesis, Department of Systems Ecology, Stockholm University 
Arrhenius F, Hansson S (1993) Food consumption of larvali young and adult herring and sprat in the Baltic Sea. Mar Ecol Prog Ser 96:125-1.37

Astok V, Matthäus W, Berzins V, Carlberg S, Cyberska B, Elken J, Lange W, Launiainen J, Nomm A, Suursaar $Y$, Tamsalu R, Vihma T (1990) Hydrography. In: Baltic Marine Environment Protection Commission, Helsinki Commission. Second periodic assessment of the state of the marine environment of the Baltic Sea, 1984-1988: Background document. Baltic Sea Environ Proc 35B:21-68

Bagge O. Thurow F, Steffensen E, Bay J (1994) The Baltic cod. Dana 10:1-28

Bergström S, Carlsson B (1994) River runoff to the Baltic Sea 1950-1990. Ambio 23:4-5

Elliott JM (1971) Some methods for the statistical analysis of samples of benthic invertebtes. Freshwat Biol Assoc Sci Publ 25. Titus Wilson \& Son Ltd, Kendal

Flinkman J, Aro E, Vuorinen I, Kotilainen P (1991) The annual changes in food selection of Baltic herring. ICES CM 1991/ $\mathrm{J}: 14$

Flinkman J, Vuorinen I, Aro E (1992) Planktivorous Baltic herring (Clupea harengus) prey selectively on reproducing copepods and cladocerans. Can J Fish Aquat Sci 49:73-77

Hansson S, Larsson U, Johansson S (1990) Selective predation by herring and mysids, and zooplankton community structure in the Baltic Sea coastal area. J Plankton Res 12 : $1099-1116$

Hario $M$ (1990) Breeding failure and feeding conditions of lesser black-backed gulls Larus f. fuscus in the Gulf of Finland Ornis Fenn 67:113-129

Hernroth L (ed) (1985) Recommendations on methods for marine biological studies in the Baltic Sea. Mesozooplankton biomass assessment. Baltic Mar Biol Publ 10:1-32

Hernroth L, Ackefors H (1979) The zooplankton of the Baltic proper. A long-term investigation of the fauna, its biology and ecology. Rep Fish Swedish Inst Mar Res 2:1-60

Kiørboe T (1993) Turbulence, phytoplankton cell size, and the structure of pelagic food webs. Adv Mar Biol 29:1-72

Kiørboe T, Johansen K (1986) Studies of larval herring (Clupea harengus L.) patch in the Buchan area. IV. Zooplankton distribution and productivity in relation to hydrodynamic features. Dana 6:37-51

Kiørboe T, Kaas H, Kruse B, Mohlenberg F, Tiselius P, Fertebjerg $G(1990)$ The structure of the pelagic food web in relation to water column structure in the Skagerrak. Mar Ecol Prog Ser 59:19-32

Lazarro X (1987) A review of planktivorous fishes: their evolution, feeding behaviours, selectivities, and impacts Hydrobiologia 146:97-167

Lumberg $H$, Ojaveer E (1991) On the environment and zooplankton dynamics in the Gulf of Finland in 1961-1.990. Proc Est Acad Sci Ecol 1, N3:131-140

MacKenzie B, St. John M, Wieland K (1996) Eastern Baltic cod: perspectives from existing data on processes affecting growth and survival of eggs and larvae. Mar Ecol Prog Ser 134:265-281

Matthäus W, Franck H (1992) Characteristics of major Baltic inflows - a statistical analysis. Cont Shelf Res 12:1375-1400

Matthäus W, Schinke H (1994) Mean atmospheric circulathon patterns associated with major Baltic inflows. Ger J Hydrogr 46:321-339

Munk P (1993) Differential growth of larval sprat Sprattus sprattus across a tidal front in the eastern North Sea. Mar Ecol Prog Ser 99:17-27

Munk P, Larsson PO, Danielsen D, Moksness E (1995) Larval and small juvenile cod Gadus morhua concentrated in the highly productive areas of a shelf break front. Mar Ecol
Prog Ser 125:21-30

Nissling A, Westin L (1991) Egg mortality and hatching rate of Baltic cod (Gadus morhua) in different salinities. Mar Biol 111:29-32

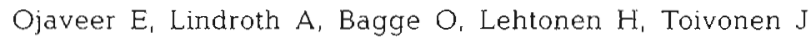
(1981) Fish and fisheries. In: Voipio A (ed) The Baltic Sea. Elsevier Sci Publ Co, Amsterdam, p 275-350

Parmanne R (1990) Growth, morphological variation and migrations of herring (Clupea harengus L.) in the northern Baltic Sea. Finn Fish Res 10:1-48

Parmanne R, Rechlin O, Sjöstrand B (1994) Status and future of herring and sprat stocks in the Baltic Sea. Dana 10:29-59

Pearre S (1982) Estimating prey preference by predators: uses of various indices, and a proposal of another based on $\chi^{2}$. Can J Fish Aquat Sci 39:914-923

Popiel J (1951) Feeding and food of the herring (Clupea harengus L.) in the Gulf of Gdansk and in the adjoining waters. Pr Morsk Inst Ryb Gdyni 6:29-56

Raid T, Lankov A. (1995) Recent changes in the growth and feeding of the Baltic herring and sprat in the northeastern Baltic Sea. Proc Est Acad Sci Ecol 5(1/2):38-55

Rajasilta M (1992) Relationship between food, fat sexual maturation, and spawning time of Baltic herring (Clupea harengus membras) in the Archipelago Sea. Can J Fish Aquat Sci 49:644-654

Richardson K (1985) Plankton distribution and activity in the North Sea/Skagerrak frontal area in April 1984. Mar Ecol Prog Ser 26:233-244

Rudstam LG, Aneer G, Hildén M (1994) Top-down control in the pelagic Baltic ecosystem. Dana 10:105-129

Rudstam LG, Hansson S, Johansson S, Larsson U (1992) Dynamics of planktivory in a coastal area of the northern Baltic Sea. Mar Ecol Prog Ser 80:159-173

Salonen K (1979) A versatile method for rapid and accurate determination of carbon by high temperature combustion. Limnol Oceanogr 24:177-183

Sandström O (1980) Selective feeding by Baltic herring. Hydrobiologia 69:199-207

Schnack D (1974) On the biology of herring larvae in Schlei Fjord, western Baltic. Rapp P-V Réun Cons Int Explor Mer $166: 114-123$

Segerstråle SG (1969) Biological fluctuations in the Baltic Sea Prog Oceanogr 5:169-184

Sparholt H (1994) Fish species interactions in the Baltic Sea Dana 10:131-162

Sparholt H, Jensen IB (1992) The effect of cod predation on the weight-at-age of herring in the Baltic. ICES Mar Sci Symp 195:488-491.

St. John MA, Lund T (1996) Lipid biomarkers: linking the utilization of frontal plankton biomass to enhanced condition of juvenile North Sea cod. Mar Ecol Prog Ser 131:75-85

Strzyzewska K, Popiel J (1974) Changes in the growth of herring in the Southern Baltic. Ber Dtsch Wiss Komm Meeresforsch 23:268-272

Thürow F (1997) Estimation of the total fish biomass in the Baltic Sea durng the 20th century. ICES J Mar Sci 54:444-461

Viitasalo M, Vuorinen I, Saesmaa S (1995) Mesozooplankton dynamics in the northern Baltic Sea: implications of variations in hydrography and climate. J Plankton Res 17 $1857-1878$

Westin L, Nissling A (1991) Effects of salinity on spermatozod motility, percentage of fertilized eggs and egg development of Baltic cod (Gadus morhua), and implications for cod stock fluctuations in the Baltic. Mar Biol 108:5-9

Wieland K, Waller U, Schnack D (1994) Development of Baltic cod eggs at different levels of temperature and oxygen content. Dana 10:163-177 